\title{
Degenerescence of virus-free garlic cultivars in altitude conditions in the Semiarid region of the Northeast of Brazil
}

\author{
Antonia TM Bessa ${ }^{1} \mathbb{D}$; Maria Zuleide de Negreiros ${ }^{1} \mathbb{D}$; Welder de AR Lopes $^{1} \mathbb{D}$; Francisco V Resende ${ }^{2} \mathbb{D}$; \\ Glauber Henrique de S Nunes ${ }^{1} \mathbb{D}$; Laíza G de Paiva ${ }^{1} \mathbb{D}$; Mayky FP de Lima ${ }^{3} \mathbb{D}$; Renan da C Paulino ${ }^{1} \mathbb{D}$; Leilson \\ C Grangeiro' ${ }^{1} \mathbb{D}$
}

${ }^{1}$ Universidade Federal Rural do Semi-Árido (UFERSA), Mossoró-RN, Brasil; tami.bessa@hotmail.com; zuleide@ufersa.edu.br; welder. lopes@hotmail.com; glauber@ufersa.edu.br; laizagomes@outlook.com; renan@ufersa.edu.br; leilson@ufersa.edu.br; ${ }^{2 E m b r a p a ~ H o r t a l i c ̧ a s, ~}$ Brasília-DF, Brasil; francisco.resende@embrapa.br; ${ }^{3}$ Serviço Social da Indústria (SESI); Mossoró-RN, Brasil; maykylima@bol.com.br

\begin{abstract}
It is necessary to use virus-free garlic seeds to reach high bulb yields; however, information is needed on the number of generations that these seeds can be grown in field conditions without decreasing bulb yield and quality due to degeneration. Degeneration is dependent on the production season and locality; thus, the objective of this work was to evaluate the degeneration of virus-free garlic cultivars grown in the Semiarid region of the Northeast of Brazil, through three experiments conducted in Portalegre, state of Rio Grande do Norte. Virus-free garlic cultivars were used in the first generation (G1) and second-generation (G2) and cultivars without clonal cleaning (infected) in the third experiment. The experiments were conducted in randomized blocks experimental design, with four replications. The treatments consisted of five cultivars: Amarante, Branco Mossoró, Cateto Roxo, Gravatá, and Hozan. The use of G2 garlic seeds in field conditions is viable, mainly for the cultivars Branco Mossoró and Hozan, which showed lower production losses. However, further evaluations, considering at least four generations, are necessary for these cultivars, since the degeneration level depends on the crop environment.
\end{abstract}

Keywords: Allium sativum, plant health, reinfection, mean bulb weight, yield.

\section{RESUMO}

Degenerescência de cultivares de alho livre de vírus em condições de altitude no Semiárido nordestino

O emprego de alho-semente livre de vírus é uma necessidade para obtenção de altos rendimentos; porém, é necessário avaliar quantas gerações esse material pode ser cultivado em campo sem que a degenerescência cause redução de produção e de qualidade. Como a degenerescência é dependente do local e época de produção, este trabalho teve o objetivo de avaliar a degenerescência de cultivares de alho livre de vírus em condições de altitude no semiárido nordestino por meio de três experimentos contíguos desenvolvidos em PortalegreRN. No primeiro experimento, utilizaram-se cultivares livre de vírus (LV) de primeira geração (G1); no segundo, as cultivares LV de segunda geração (G2) e no terceiro, as cultivares que não passaram pela limpeza clonal (infectadas). O delineamento experimental empregado, nos três experimentos, foi de blocos casualizados com quatro repetições. Os tratamentos foram constituídos pelas cultivares Amarante, Branco Mossoró, Cateto Roxo, Gravatá e Hozan. Concluise que até a G2 é viável a utilização do alho-semente no campo, principalmente das cultivares Branco Mossoró e Hozan por terem registrado menores perdas de produção. No entanto, é necessário avaliar esses materiais ao longo de pelo menos quatro gerações, uma vez que o grau de degenerescência depende do ambiente de cultivo.

Palavras-chave: Allium sativum, sanidade, reinfecção, peso médio do bulbo, produtividade.

Received on May 22, 2020; accepted on April 8, 2021

$\mathrm{G}$ arlic production in Brazil reached $118.837 \mathrm{t}$ in 2018 (IBGE, 2020), which represents only $42 \%$ of the Brazilian domestic consumption. However, garlic yield in Brazil has considerably increased in the last years, due to the development of new technologies and, mainly, the adoption of virus-free garlic seeds in the producing regions.
The use of virus-free garlic seeds from clonal cleaning usually results in more vigorous and taller plants, greater numbers of leaves, and higher bulb quality and yield (Fernandes et al., 2013). Diseases caused by several virus species are the main cause of garlic-seed degeneration, gradually causing decrease of the vegetative vigor, productive potential, and bulb quality over the crop generations (Resende $e t$ al., 2016).

Melo Filho et al. (2006) evaluated garlic cultivars for seven years and obtained a yield increase of $141 \%$ for virus-free plants when compared to those infected by viruses in the first crop cycle, and an increase of $49 \%$ in the fifth cycle. Silva et al. (2010) found that virus-free cultivars (Gigante 
Roxo, Gravatá, Gigante de Lavínia, and Gigante-Roxão) can be multiplied in field conditions for at least nine consecutive years, with decreasing production after the third or fourth crop year, depending on the cultivar.

Thus, the reinfection level throughout successive multiplication (generations) depends on the tolerance of the cultivar, populational level of vectors, and distance form infected crops (Fernandes et al., 2013). Despite the existence of studies in some regions of Brazil and other countries on viral reinfection of garlic crops in field conditions, no study was found for the state of Rio Grande do Norte, Brazil.

In this context, the objective of this work was to evaluate the degeneration of virus-free garlic cultivars in two consecutive years and a third experiment with infected cultivars, conducted in Portalegre, state of Rio Grande do Norte, in the Semiarid region of the Northeast Brazil.

\section{MATERIAL AND METHODS}

Three experiments were conducted in field conditions from May to October, 2018 , in the municipality of PortalegreRN, Brazil (6 $6^{\circ} 1^{\prime} 20^{\prime \prime} \mathrm{S}, 38^{\circ} 1^{\prime} 45^{\prime \prime} \mathrm{W}, 520$ $m$ altitude). The region presents an Aw, tropical rainy climate, according to the Köppen classification, with dry winter, a rainy season extending up to July, and mean annual rainfall depths between 800 and $1.200 \mathrm{~mm}$ (Seplan, 2014). The minimum, mean, and maximum temperatures during the experiments were 15 to $21,24.7$, and 26 to $34^{\circ} \mathrm{C}$, respectively.

The soil of the experimental area was classified as eutrophic Lithic Quartzipsamment (Neossolo Litólico Eutrófico; Embrapa, 2018) of weak A horizon and medium texture. The soil chemical analysis showed $\mathrm{pH}\left(\mathrm{H}_{2} \mathrm{O}\right)=$ $6.2 ; \mathrm{P}=53.4 \mathrm{mg} \mathrm{dm}^{-3} ; \mathrm{K}=241.9 \mathrm{mg}$ $\mathrm{dm}^{-3} ; \mathrm{Na}=190.9 \mathrm{mg} \mathrm{dm}{ }^{-3} ; \mathrm{Ca}=3.7$ $\mathrm{cmol}_{\mathrm{c}} \mathrm{dm}^{-3} ; \mathrm{Mg}=1.4 \mathrm{cmol}_{\mathrm{c}} \mathrm{dm}^{-3} ; \mathrm{Al}=$ $0.0 \mathrm{cmol}_{\mathrm{c}} \mathrm{dm}^{-3} ; \mathrm{H}+\mathrm{Al}=0.83 \mathrm{cmol}_{\text {c }}$ $\mathrm{dm}^{-3}$; sum of bases of $6.55 \mathrm{cmol} \mathrm{dm}^{-3}$; cation exchange capacity $(\mathrm{CEC})=7.37$ $\mathrm{cmol}_{\mathrm{c}} \mathrm{dm}^{-3}$; effective $\mathrm{CEC}=6.55 \mathrm{cmol}_{\mathrm{c}}$ $\mathrm{dm}^{-3}$; base saturation of $89 \%$, aluminum saturation of $0.0 \%$, and exchangeable sodium percentage of $11 \%$.

Virus-free garlic cultivars were used in the first-generation (G1) and second-generation (G2) and cultivars without clonal cleaning (infected) in the third experiment. The experiments were conducted in randomized block experimental design, with four replications. The treatments consisted of five garlic cultivars (Amarante, Branco Mossoró, Cateto Roxo, Gravatá, and Hozan), acquired from the Brazilian Agricultural Research Corporation (Embrapa Hortaliças), Brasília-DF, Brazil. The virus-free garlic cultivars passed through a clonal cleaning process and were multiplied in controlled conditions, under shade-screen (G0). These clones $(\mathrm{G} 0)$ were grown for the first time in field conditions (G1 generation), and second time in field conditions ( $\mathrm{G} 2$ generation).

The experimental plots consisted of beds $(0.20 \mathrm{~m}$ height, $1.0 \mathrm{~m}$ width, and $2.0 \mathrm{~m}$ length) with five longitudinal planting rows. Bulbils were planted at $5 \mathrm{~cm}$ depth, spaced $20 \mathrm{~cm}$ between rows and $10 \mathrm{~cm}$ between plants, forming a population of 100 plants in a total area of $2.0 \mathrm{~m}^{2}$. The evaluated area of each plot consisted of the three central rows, discarding one plant of each end of the rows, resulting in a population of 54 plants in an area of $1.08 \mathrm{~m}^{2}$.

The soil was plowed and harrowed, followed by the bed raising using a motocultivator. Soil fertilizers were applied at planting, based on the soil analysis and chemical recommendations of Holanda et al. (2017) and Resende et al. (2004), using $30 \mathrm{~kg} \mathrm{ha}^{-1} \mathrm{~N}$ (ammonium sulfate), $60 \mathrm{~kg} \mathrm{ha}^{-1} \mathrm{P}_{2} \mathrm{O}_{5}$ (simple superphosphate), $20 \mathrm{~kg} \mathrm{ha}^{-1}$ $\mathrm{K}_{2} \mathrm{O}$ (potassium chloride), $14 \mathrm{~kg} \mathrm{ha}^{-1}$ $\mathrm{Mg}$ (magnesium sulfate), $12 \mathrm{~kg} \mathrm{ha}^{-1} \mathrm{Zn}$ (zinc sulfate), $1.7 \mathrm{~kg} \mathrm{ha}^{-1} \mathrm{~B}$ (boric acid), and $75 \mathrm{t} \mathrm{ha}^{-1}$ of Pole Fértil ${ }^{\circledR}$ (bovine and chicken manure-based fertilizer containing $1 \% \mathrm{~N}, 15 \%$ organic $\mathrm{C}, 15 \%$ moisture, $\mathrm{pH}$ of 6.20 , and CTC of 74 $\left.\mathrm{mmol}_{\mathrm{c}} \mathrm{dm}^{-3}\right)$. $\mathrm{N}$ fertilizer was applied as topdressing, 30 days after planting (DAP), using $30 \mathrm{~kg} \mathrm{ha}^{-1}$ of $\mathrm{N}$ (urea), and at $60 \mathrm{DAP}$, using $30 \mathrm{~kg} \mathrm{ha}^{-1}$ of $\mathrm{N}$ (urea) and $13 \mathrm{~kg} \mathrm{ha}^{-1}$ of $\mathrm{K}_{2} \mathrm{O}$ (potassium nitrate).
The bulbs were threshed and cloves classified by size and treated with a $2.5 \%$ iprodione solution before planting to prevent attacks of soil pathogens. The plants were protected from purple spot using mancozeb-based (Manzate ${ }^{\odot}$ WG) and azoxystrobin-based (Amistar ${ }^{\circ}$ WG) products, and from pests, such as thrips and mites, using a chlorfenapyrbased product (Pirate $\left.{ }^{\circledR}\right)$. Weeds were controlled by manual weeding when required.

A micro-sprinkler irrigation system was used, with flow of $40 \mathrm{~L} \mathrm{~h}^{-1}$ and pressure of $200 \mathrm{KPa}$. The irrigation was suspended five days before the harvest at the first sign of plant's maturation, characterized by the yellowing and dry of two thirds of the shoots.

The plants were harvested manually and subjected to a pre-cure process, remaining for three days exposed to the sun, and a shade cure process, remaining for 17 days in a dry, airy, shaded place.

Plant height $(\mathrm{cm})$ from the ground level to the end of the longest leaf, and number of photosynthetically active leaves/plant were evaluated at 75 days after planting, in a sample of ten plants. Mean bulb weight (g); total bulb yield $\left(\mathrm{t} \mathrm{ha} \mathrm{a}^{-1}\right)$ of each plot; commercial bulb yield $\left(t \mathrm{ha}^{-1}\right)$ considering bulbs with transversal diameter above $32 \mathrm{~mm}$, and mean number of cloves per bulb were evaluated after the cure and cleaning of the bulbs.

Obtained data were subjected to analyses of variance, separately for each experiment. After meeting the assumptions of homogeneity of variances and normality of errors between experiments, the data were subjected to joint analyses of variance; the means referring to plant health and cultivars were compared by the ScottKnott test $(p \leq 0.05)$, using the Sisvar ${ }^{\mathbb{B}}$ 5.4 program (Ferreira, 2011).

\section{RESULTS AND DISCUSSION}

The effect of the interaction between garlic-seed health and cultivars was significant for the mean bulb weight, total bulb yield (TBY), and number of cloves per bulb (NCB). The isolate effects of garlic-seed health and cultivars were significant for plant height, number 
of leaves/plant (NLP), and commercial bulb yield (CBY).

The first-generation (G1) virus-free garlic seeds resulted in $15.73 \%$ higher plant heights than the second generation (G2) and infected seeds (Table 1), whereas G2 had $10.41 \%$ lower plant height than the infected seeds, denoting that the plant vigor decreases as the reinfection level is increased.

Resende et al. (1999) found 29\% higher plant height for virus-free plants when compared to infected ones. Lima (2019) found higher plant height means for virus-free garlic $(65.46 \mathrm{~cm})$ when compared to infected plants $(54.57 \mathrm{~cm})$.

Studies have shown that the use of virus-free garlic seeds results in plants with higher vegetative vigor than the use of infected seeds, and that the garlicseed vigor decreases after successive generations (Fernandes et al., 2013; Resende et al., 2000).

The evaluated cultivars showed variation in plant height; Hozan presented the highest mean $(67.73 \mathrm{~cm})$, followed by Branco Mossoró (58.03 $\mathrm{cm})$, Amarante $(47.39 \mathrm{~cm})$, Cateto Roxo $(44.21 \mathrm{~cm})$, and Gravatá $(43.64 \mathrm{~cm})$ (Table 1).

Honorato et al. (2013) found similar plant heights to those found in the present study for the cultivars Amarante $(47 \mathrm{~cm})$, Branco Mossoró $(50 \mathrm{~cm})$, Cateto Roxo ( $44.75 \mathrm{~cm})$, Gravatá (44.5 $\mathrm{cm})$, and Hozan $(61.25 \mathrm{~cm})$. In addition, Oliveira et al. (2010) found that plants of the cultivars Amarante, Gravata, Cateto Roxo, and Hozan reached heights from 42.7 to $46.5 \mathrm{~cm}$, indicating that the crop environment affects the vegetative vigor of garlic cultivars.

Virus-free plants presented higher NLP (7.89) than infected ones (7.12), despite the little variation in garlic-seed health (Table 1). This result confirms those reported by Melo Filho et al. (2006), who found little variation in NLP between generations of virus-free garlic seeds and a control (infected garlic).

Plants of cultivar Hozan presented the lowest NLP mean (6.59), and the other cultivars presented no differences between them, with a mean of 7.89 leaves/plant (Table 1).

Honorato et al. (2013) found similar results, with higher NLP for Amarante,
Branco Mossoró, and Gravatá, when compared to the cultivar Hozan, but, Hozan presented a lower mean (4.75) than that found in the present study. This can be explained by the less favorable climate conditions of Mossoró (18 m altitude) for this cultivar when compared to Portalegre (520 m altitude). Number of leaves/plant is an important factor to obtain high yields and, combined with plant height, for the assimilatory performance during the crop cycle, which is related to the final garlic bulb production (Lopes et al., 2016; Lima, 2019).

G1 plants from virus-free garlic seeds presented higher mean bulb weight (MBW) than G2 and infected plants (Table 2). The lower MBW in G2, when compared to G1 plants, varied between cultivars, presenting values of $3.68 \%$ (Amarante), $3.93 \%$ (Branco Mossoró), 18.36\% (Cateto Roxo), Gravatá (47.62\%), and 4.03\% (Hozan). Significant lower MBW means were found for Cateto Roxo and Gravatá, indicating a higher sensitivity of these cultivars to environmental pressures.

G2 plants of virus-free garlic cultivars presented higher MBW than infected cultivars, except for Gravatá, with 35.33\% (Amarante), 22.40\% (Branco Mossoró), 34.89\% (Cateto Roxo), and $18.75 \%$ (Hozan). Melo Filho et al. (2006) found significantly higher MBW for the cultivar Amarante until the fourth generation when compared to the control treatment (infected), which presented a reduction of $41.76 \%$ and $37.08 \%$ compared to G1 and G2, respectively. Conci et al. (2003) evaluated garlic cultivars in Argentina and found significant lower MBW for garlic seeds used for five cycles in field conditions, $75.70 \mathrm{~g}$ for $\mathrm{G} 1$, and $49.9 \mathrm{~g}$ for G5, corresponding to a $34.08 \%$ loss; however, G5 presented significantly higher plants than the control (infected), which presented a MBW of $33.4 \mathrm{~g}$.

Among G1 plants, the highest MBW means were found for the cultivars Gravatá (24.17 g) and Hozan (24.82 g). Among G2 and infected plants, the Branco Mossoró and Hozan presented higher MBW than cultivars Amarante, Cateto Roxo, and Gravatá. Gravatá presented high viral reinfection, presenting lower MBW than the other cultivars in G2 (Table 2).

Soares et al. (2015) evaluated garlic cultivars without clonal cleaning process and found similar results to those obtained in the present study for cultivars Amarante (10 g), Branco Mossoró (16.75 g), and Cateto Roxo $(11.75 \mathrm{~g})$. Despite being these cultivars tested under less favorable climate conditions than those of Portalegre, the infection level of these cultivars was probably lower than that found in the present study.

Total bulb yield presented similar results to those found for MBW, which were lower in the $\mathrm{G} 2$ plants, with means

Table 1. Mean plant height, number of leaves, and commercial yield of first-generation (G1) and second-generation (G2) garlic cultivars as a function of the garlic-seed health. Portalegre, UFERSA, 2018.

\begin{tabular}{|c|c|c|c|}
\hline Seed heath & $\begin{array}{c}\text { Plant height } \\
\text { (cm) }\end{array}$ & $\begin{array}{c}\text { Number of leaves } \\
\text { (leaves/plant) }\end{array}$ & $\begin{array}{c}\text { Commercial yield } \\
\left(t \text { ha }^{-1}\right)\end{array}$ \\
\hline Virus-free (G1) & $59.16 \mathrm{a}$ & $7.97 \mathrm{a}$ & $7.64 \mathrm{a}$ \\
\hline Virus-free (G2) & $51.12 \mathrm{~b}$ & $7.81 \mathrm{a}$ & $6.12 \mathrm{~b}$ \\
\hline Infected & $46.32 \mathrm{c}$ & $7.12 \mathrm{~b}$ & $4.12 \mathrm{c}$ \\
\hline \multicolumn{4}{|l|}{ Cultivars } \\
\hline Amarante & $47.39 \mathrm{c}$ & $7.98 \mathrm{a}$ & $4.58 \mathrm{~b}$ \\
\hline Branco Mossoró & $58.03 \mathrm{~b}$ & $8.08 \mathrm{a}$ & $6.80 \mathrm{a}$ \\
\hline Cateto Roxo & $44.21 \mathrm{c}$ & $7.58 \mathrm{a}$ & $5.63 \mathrm{~b}$ \\
\hline Gravatá & $43.64 \mathrm{c}$ & $7.93 \mathrm{a}$ & $5.04 \mathrm{~b}$ \\
\hline Hozan & $67.73 \mathrm{a}$ & $6.59 \mathrm{~b}$ & $7.77 \mathrm{a}$ \\
\hline CV (\%) & 8.97 & 8.44 & 24.65 \\
\hline
\end{tabular}

Means followed by the same letter in the columns are not different from each other by the Scott-Knott test at 5\% probability. 
varying according to the tolerance of the cultivars to viral reinfection. The cultivars Cateto Roxo and Gravatá presented TBY of $16.97 \%$ and $47.15 \%$, respectively, in $\mathrm{G} 1$, and the other cultivars presented TBY lower than $3.5 \%$. According to Silva et al. (2010), the reinfection level over successive generations under field conditions depends on the tolerance of the cultivar and the vector populations. Infected plants of all cultivars, except Gravatá, presented significantly lower TBY in G2, 46.09\% lower for Amarante, 24.26\% lower for Branco Mossoró, $37.11 \%$ lower for Cateto Roxo, and 21.94\% lower for Hozan (Table 2). Melo Filho et al. (2006) found yield decreases of $17.88 \%$ in $\mathrm{G} 2$ and $39.66 \%$ in G7 for the cultivar Amarante over crop cycles; however, the yield of G7 was $31.44 \%$ higher than that of infected plants, denoting the viability of using this cultivar as garlic-seed until the seventh generation.

Among G1 plants, Amarante presented the lowest TBY (5.10 $\left.\mathrm{t} \mathrm{ha}^{-1}\right)$; the other cultivars presented higher means with no differences between them. Among G2 and infected plants, the TBY varied between cultivars, with Branco Mossoró and Hozan presenting the highest means (Table 2).

Soares et al. (2015) evaluated garlic cultivars in Governador Dix-sept Rosado-RN, Brazil, and found variation

Table 2. Mean bulb weight, total bulb yield, and number of cloves per bulb of first-generation (G1) and second-generation (G2) garlic cultivars as a function of seed health. Portalegre, UFERSA, 2018.

\begin{tabular}{|c|c|c|c|c|}
\hline \multirow[t]{2}{*}{ Cultivars } & $\begin{array}{c}\text { Virus-free } \\
\text { (G1) }\end{array}$ & $\begin{array}{c}\text { Virus-free } \\
\text { (G2) }\end{array}$ & Infected & Mean \\
\hline & \multicolumn{4}{|c|}{ Mean bulb weight (g) } \\
\hline Amarante & $17.16 \mathrm{Ab}$ & $16.53 \mathrm{Ab}$ & $10.69 \mathrm{Bb}$ & $14.79 \mathrm{c}$ \\
\hline $\begin{array}{l}\text { Branco } \\
\text { Mossoró }\end{array}$ & $20.59 \mathrm{Ab}$ & $19.78 \mathrm{Aa}$ & $15.35 \mathrm{Ba}$ & $18.57 \mathrm{~b}$ \\
\hline Cateto Roxo & $20.92 \mathrm{Ab}$ & $17.08 \mathrm{Ab}$ & $11.12 \mathrm{Bb}$ & $16.37 \mathrm{c}$ \\
\hline Gravatá & $24.17 \mathrm{Aa}$ & $12.66 \mathrm{Bb}$ & $10.44 \mathrm{Bb}$ & $15.75 \mathrm{c}$ \\
\hline Hozan & $24.82 \mathrm{Aa}$ & $23.09 \mathrm{Aa}$ & $18.76 \mathrm{Ba}$ & $22.22 \mathrm{a}$ \\
\hline Means & $21.53 \mathrm{~A}$ & $17.83 \mathrm{~B}$ & $13.27 \mathrm{C}$ & \\
\hline \multirow[t]{2}{*}{ CV (\%) } & \multicolumn{4}{|c|}{18.31} \\
\hline & \multicolumn{4}{|c|}{ Total bulb yield (t ha' $\left.{ }^{-1}\right)$} \\
\hline Amarante & $5.10 \mathrm{Ab}$ & $6.01 \mathrm{Ab}$ & $3.24 \mathrm{Bb}$ & $4.78 \mathrm{~d}$ \\
\hline $\begin{array}{l}\text { Branco } \\
\text { Mossoró }\end{array}$ & $7.69 \mathrm{Aa}$ & $7.42 \mathrm{Aa}$ & $5.62 \mathrm{Ba}$ & $6.91 \mathrm{~b}$ \\
\hline Cateto Roxo & $7.66 \mathrm{Aa}$ & $6.36 \mathrm{Ab}$ & $4.00 \mathrm{Bb}$ & $6.00 \mathrm{c}$ \\
\hline Gravatá & $8.61 \mathrm{Aa}$ & $4.55 \mathrm{Bc}$ & $3.73 \mathrm{Bb}$ & $5.63 \mathrm{c}$ \\
\hline Hozan & $8.91 \mathrm{Aa}$ & $8.66 \mathrm{Aa}$ & $6.76 \mathrm{Ba}$ & $8.11 \mathrm{a}$ \\
\hline Means & $7.59 \mathrm{~A}$ & $6.60 \mathrm{~B}$ & $4.67 \mathrm{C}$ & \\
\hline CV (\%) & \multicolumn{4}{|c|}{17.26} \\
\hline
\end{tabular}

\begin{tabular}{lcccc}
\hline \multicolumn{5}{c}{ Number of cloves per bulb } \\
\hline Amarante & $5.13 \mathrm{Ad}$ & $3.73 \mathrm{Ac}$ & $5.38 \mathrm{Ab}$ & $4.74 \mathrm{c}$ \\
Branco & $11.88 \mathrm{Bb}$ & $14.53 \mathrm{Aa}$ & $16.70 \mathrm{Aa}$ & $14.37 \mathrm{a}$ \\
Mossoró & $11.03 \mathrm{Ab}$ & $8.70 \mathrm{Ab}$ & $6.03 \mathrm{Bb}$ & $8.58 \mathrm{~b}$ \\
Cateto Roxo & $16.20 \mathrm{Aa}$ & $2.55 \mathrm{Bc}$ & $4.15 \mathrm{Bb}$ & $7.63 \mathrm{~b}$ \\
Gravatá & $9.33 \mathrm{Ac}$ & $9.05 \mathrm{Ab}$ & $7.25 \mathrm{Ab}$ & $8.54 \mathrm{~b}$ \\
Hozan & $10.71 \mathrm{~A}$ & $7.71 \mathrm{~B}$ & $7.90 \mathrm{~B}$ \\
\hline Means & \multicolumn{5}{c}{28.47} \\
CV (\%) & \multicolumn{5}{c}{} \\
\hline
\end{tabular}

Means followed by the same uppercase letter in the rows, or lowercase in the columns, are not different from each other by the Scott-Knott test at $5 \%$ probability. in TBY between cultivars, with the cultivar Branco Mossoró presenting the highest yields. Lucena et al. (2016) found different TBY for plants of the cultivar Hozan grown in Baraúna, (4.33 tha $^{-1}$ ) and Governador Dix-sept Rosado $\left(2.88 \mathrm{tha}^{-1}\right)$. These results denote the lower adaptability of this cultivar to low-altitude conditions when compared to the results found in Portalegre (higher altitude).

G1 plants from virus-free garlic seeds presented $19.90 \%$ higher CBY than G2, and $46.07 \%$ higher than infected plants (Table 1), and G2 plants presented $32.68 \%$ higher CBY than infected plants. These results indicate that the plants underwent viral infection in the first crop year in field conditions, resulting in lower CBY when compared to G2. However, this lower CBY of G2 does not justify, economically, the removal of these plants for the planting of new virus-free garlic seeds, since despite the decrease in CBY after only two production cycles (G2), their CBY was higher than that of infected plants. In addition, Conci et al. (2003) and Melo Filho et al. (2006) found that G1 virus-free plants in field conditions are rapidly infected by virus, affecting the plant vigor and, consequently, the yields over generations, with yield decreases up to the fourth (Conci et al., 2003) and fifth generations (Melo Filho et $a l ., 2006$ ), but with higher yield than infected plants.

The highest CBY was found for the cultivars Branco Mossoró (6.80 t ha-1) and Hozan $\left(7.77\right.$ t ha $\left.^{-1}\right)$ (Table 1), which denotes the higher tolerance to viruses and adaptability to the edaphoclimatic conditions of Portalegre.

$\mathrm{NCB}$ varies between cultivars according to the seed health. G1 plants of all cultivars, except Branco Mossoró, presented lower NCB in G2, especially Gravatá, representing decreases of 27.29\% (Amarante), 21.12\% (Cateto Roxo), $84.26 \%$ (Gravatá), and $3.00 \%$ (Hozan) (Table 2). These results confirm those reported by Pedrosa (2015), who found lower NCB for virus-free garlic cultivars of the noble group in the second crop year in field conditions (G2).

The NCB of G1 plants varied from 5.13 to 16.20 , the highest mean was found for the cultivar Gravatá, followed 
by Branco Mossoró, Cateto Roxo, Hozan, and Amarante. The highest NCB of G2 and infected plants was found for Branco Mossoró cultivar, whereas Amarante and Gravatá presented the lowest NBC (Table 2). However, Amarante and Hozan are from the seminoble group, with NCB varying from 8 to 15 , whereas the others are early-maturation cultivars with higher NCB (Resende et al., 2017). Although $\mathrm{NCB}$ is a genetic characteristic, it can be affected by environmental factors, such as photoperiod and temperature, which affect cell differentiation and formation of garlic bulbs with good quality (Lopes et al., 2016; Lima, 2019).

The results showed that the yields of second-generation plants of the garlic cultivars used were lower due to the viral reinfection that occured naturally in field conditions. However, the seeds of these cultivars can be used for more generations in subsequent garlic crops, since they presented higher yield than the infected plants.

Thus, the use of G1 and G2 garlic seeds is viable under field conditions, mainly for the cultivars Branco Mossoró and Hozan, which showed lower production losses caused by degeneration. However, evaluating these cultivars for at least four generations under the climate conditions of the Semiarid region of the Northeast of Brazil is needed, since the degeneration level depends on the crop environment and the conditions of this region favor the multiplication of virus vectors, promoting the reinfection of garlic seeds more rapidly and with higher intensity than that found in the Central-West and Southwest regions of the country.

\section{ACKNOWLEDGEMENTS}

The authors thank the Brazilian National Council for Scientific and
Technological Development (CNPq) for the financial support for this study and for granting a research productivity scholarship (PQ2) to second author; and the Brazilian Coordination for the Improvement of Higher Education Personnel (CAPES) for granting a doctoral scholarship to the first author.

\section{REFERENCES}

CONCI, VC; CANAVELLI, A; LUNELLO, P; DI RIENZO, J; NOME, SF; ZUMELZU, G; ITALIA, R. 2003. Yield losses associated with virus-infected garlic plants during five successive years. Plant Disease 87: 14111415.

EMBRAPA. 2018. Sistema brasileiro de classificação de solos. Brasília: Embrapa. 590p.

FERNANDES, FR; DUSI, AN; RESENDE, FV. 2013. Viroses do alho no Brasil: importância e principais medidas de controle. Embrapa. Available at $<$ https://www.embrapa.br/en/ busca-de-publicacoes/-/publicacao/960644/ viroses-do alho-no-brasil-importancia-eprincipais-medidas-de-controle $>$. Accessed January $15,2020$.

FERREIRA, DF. Sisvar: a computer statistical analysis system. 2011. Ciência e Agrotecnologia 35: 1039-1042.

HOLANDA, JS; DANTAS, JA; MEDEIROS, AA; NETO, MF; MEDEIROS, JF; GUEDES, FX. 2017. Indicações para adubação de culturas em solos do Rio Grande do Norte. Parnamirim, BR: EMPARN. 63p.

HONORATO, ARF. NEGREIROS, MZ; RESENDE, FV; LOPES, WAR; SOARES, AM. 2013. Avaliação de cultivares de alho na região de Mossoró. Revista Caatinga 26: 80-88.

IBGE. Instituto Brasileiro de Geografia e Estatística. 2018. Levantamento sistemático da produção agrícola. Available <http://www. ibge.gov.br>. Accessed March 5, 2020.

LIMA, MFP. 2019. Desempenho agronômico e qualidade de alho nobre livre de virus em função do tamanho do bulbilho e espaçamento de plantio em região de altitude do semiárido. Mossoró: UFERSA. 107p (Ph.D. thesis).

LOPES, WAR; NEGREIROS, MZ; MORAIS, PLD; SOARES, AM; LUCENA, RRM; SOARES, AM; SILVA, OMP; MEDEIROS, JF. 2016. Produção de alho submetido a períodos de vernalização e épocas de plantio em região de clima semiárido. Horticultura Brasileira 34: 249-256.

LUCENA, RRM; NEGREIROS, MZ; MORAIS, PLD; LOPES, WAR; SOARES, AM. 2016. Qualitative analysis of vernalizated semi-noble garlic cultivars in western Rio Grande do Norte State, Brazil. Revista Caatinga 29: 764-773.

MELO FILHO, PA; RESENDE, RO; CORDEIRO, CMT; BUSO, JA; TORRES, AC; DUSI, NA. 2006. Viral reinfection affecting bulb production in garlic after seven years of cultivation under field conditions. European Journal of Plant Pathology 116: 95-101.

PEDROSA, CE. 2015. Produção de alho-semente e degenerescência em material propagativo livre de vírus. Lavras: UFLA. 74 p (Ph.D. thesis).

RESENDE, FV; DUSI, NA; MELO, WF. Recomendações básicas para a produção de alho em pequenas propriedades. 2004. Embrapa/CNPH. Available <file:///C:/Users/ MEU\%20COM/Downloads/ct-22.pdf>. Accessed January 15, 2019.

RESENDE, FV; GUALBERTO, R; SOUZA, RJ. 2000. Crescimento e produção de clones de alho provenientes de cultura de tecidos e de propagação convencional. Scientia Agrícola 57: 61-66.

RESENDE, FV; HABER, LL; PINHEIRO, JB; MELLO, AFS. 2016. Produção de alhosemente. In: NASCIMENTO, MN; PEREIRA, RB (eds). Hortaliças de propagação vegetativa: Tecnologia de multiplicação. Brasília, DF: Embrapa. p.15-61.

RESENDE, FV; NASSUR, RCMR; HABER, LL. 2017. Cultivares recomendados. In: NICK, C; BORÉM, A (eds). Alho: do plantio à colheita. Viçosa, MG: UFV. p.67-90.

RESENDE, FV; SOUZA, RJ; FAQUIN, V; RESENDE, JTV. 1999. Comparação do crescimento e produção entre alho proveniente de cultura de tecidos e de multiplicação convencional. Horticultura Brasileira 17: 118-124.

SEPLAN - Secretaria de Estado do Planejamento e das Finanças do RN. 2014. Perfil do Rio Grande do Norte. Available <http://www. seplan.rn.gov.br/>. Accessed May 20, 2019.

SILVA, EC; SOUZA, RJ; PASQUAL, M. 2010. Diferenças de produtividade entre cultivares de alho obtidas por cultura de tecidos e multiplicação convencional, em um período de nove anos consecutivos. Bioscience Journal 26: 692-697.

SOARES, AM; NEGREIROS, MZ; RESENDE, FV; LOPES, WAR; MEDEIROS, JF; GRANGEIRO, LC. 2015. Avaliação de cultivares de alho no município de Governador Dix-sept Rosado-RN, Brasil. Revista Agroambiente 9: 423-430. 